\title{
Perbandingan Hasil Belajar Matematika Siswa antara Model Pembelajaran Langsung dengan Model Pembelajaran Make a Match Dengan Memperhitungkan Kemampuan Awal Siswa
}

\author{
Andi Jusmiana*1, Nursakiah*2 \\ *1Jurusan Pendidikan Matematika FKIP Universitas Pejuang Republik Indonesia \\ *2Jurusan Pendidikan Matematika FKIP Universitas Muhammadiyah Makassar \\ e-mail: *1andijusmiana@gmail.com ; *2 sackyah@gmail.com
}

\begin{abstract}
Abstrak
Penelitian ini merupakan penelitian eksperimen yang bertujuan untuk mengetahui perbedaan yang signifikan antara hasil matematika siswa yang diajar melalui model pembelajaran langsung pada siswa SMP Negeri 18 makassar dan siswa yang diajar melalui model pembelajaran make a match pada siswa SMP Negeri 27 Makassar. Populasi penelitian ini adalah semua SMP di kota Makassar yang berakreditasi B pada semester ganjil tahun pelajaran 2014/2015 dan dipilih secara teknik random sederhana 2 kelas sebagai sampel penelitian. Hasil yang diperoleh dari analisis statistika deskriptif adalah (1) hasil belajar matematika siswa yang diajar model pembelajaran langsung pada SMPN 18 makassar sebesar 68,78 dengan standar deviasi 8,11 dari skor ideal 100 dan (2) hasil belajar matematika siswa yang diajar melalui model pembelajaran make a match pada SMPN 27 yaitu sebesar 82,21 dengan standar deviasi 4,64 dari skor ideal 100. Dari hasil penelitian ini dapat disimpulkan bahwa pembelajaran matematika dengan model pembelajaran make a match lebih baik dibandingkan dengan model pembelajaran langsung.
\end{abstract}

Kata Kunci : Make a Match, Pembelajaran Langsung, Kemampuan awal.

\section{PENDAHULUAN}

Matematika mempunyai peran besar dalam kehidupan sehari-hari. Hampir semua aktivitas kita melibatkan kegiatan yang bersifat matematika, misalnya menghitung dan mengukur. Hampir semua mata pelajaran yang dipelajari siswa di sekolah memanfaatkan matematika dalam beberapa bagian bahasannya. Matematika merupakan ratu sekaligus pelayan bagi ilmu lain.

Walaupun matematika sangat penting dalam kehidupan manusia, akan tetapi hasil survei empat tahunan The Trends in International Mathematics and Science Study (TIMSS) pada siswa kelas VIII mengungkapkan bahwa pada keikutsertaan pertamakali tahun 1999 Indonesia berada pada peringkat 34 dari 38 negara. Pada tahun 2003 Indonesia berada pada peringkat 34 dari 46 negara. Dan ranking Indonesia pada TIMSS tahun 2007 turun menjadi ranking 36 dari 48 negara (Badan Penelitian dan Pengembangan, 2012). 
Berdasarkan hasil penelitian yang dilakukan oleh TIMSS tampak bahwa untuk masalah pemahaman matematika siswa di Indonesia jauh di bawah rata-rata Internasional. Penguasaan konsep siswa SMP di Indonesia masih rendah sehingga siswa kesulitan dalam menyelesaikan soal-soal yang tidak sering dimunculkan. Siswa sangat jarang mengajukan pertanyaan atau masalah matematika kepada guru. Mereka lebih sering berinteraksi dengan siswa lain yang berkaitan dengan materi pelajaran. Permasalahan tersebut akan berakibat pada rendahnya kemampuan komunikasi siswa yang akan bermuara pada rendahnya hasil belajar siswa.

Dengan demikian, pendidikan khususnya sekolah harus memiliki sistem pembelajaran yang menekankan pada proses dinamis yang didasarkan pada upaya meningkatkan keingintahuan siswa. Pendidikan harus mendesain pembelajarannya yang responsif dan berpusat pada siswa agar minat dan aktivitas sosial mereka terus meningkat.

Melalui model pembelajaran kooperatif tipe make a match siswa disuruh mencari pasangan kartu yang merupakan jawaban/soal sebelum batas waktu yang ditentukan dan siswa yang dapat mencocokkan kartunya diberi poin. Siswa juga diharapkan dapat memupuk kerjasama dalam menjawab pertanyaan dengan mencocokkan kartu yang ada di tangan mereka. proses pembelajaran lebih menarik dan siswa tampak lebih besemangat mengikuti proses pembelajaran, dan keaktifan siswa terlihat pada saat mereka mencari pasangan kartunya masingmasing.

Meskipun pembelajaran kooperatif sangat baik untuk diterapkan namun masih banyak pula tenaga pendidik yang menggunakan model pembelajaran langsung. Hal ini dikarenakan guru menganggap bahwa pembelajaran langsung jauh lebih mudah diterapkan daripada pembelajaran kooperatif karena dalam pembelajaran langsung guru tidak harus menyediakan media-media pembelajaran karena mereka hanya menyampaikan materi pembelajaran dengan komunikasi lisan.

\section{Jenis Penelitian}

\section{METODE PENELITIAN}

Penelitian ini merupakan jenis penelitian eksperimen, yaitu metode penelitian yang digunakan untuk mencari pengaruh tertentu terhadap yang lain dalam kondisi yang terkendalikan. Kelompok eksperimen diajar dengan menggunakan pembelajaran make a match sedangkan pada kelompok pembanding diajar dengan menggunakan pembelajaran langsung. Desain yang digunakan dalam penelitian ini adalah Desain "Pretest - Posttest Control Design".

\section{Populasi dan Sampel}

Populasi dalam penelitian ini adalah siswa kelas VIII semester ganjil SMPN Makassar yang memiliki akreditasi B. Adapun sampel dalam penelitian ini diambil dengan menggunakan Random Sampling.

\section{Instrumen Penelitian}

Untuk mengetahui hasil belajar matematika siswa dalam penelitian ini digunakan tes prestasi belajar matematika. Tes hasil belajar yang digunakan dalam penelitian ini berbentuk pilihan ganda. Sebelum tes itu digunakan terlebih dahulu diuji cobakan untuk menentukan validitas isi (content validity). Pengujian instrument penelitian dilakukan dengan validitas butir 
JURNAL SAINTIFIK VOL.2 NO.2, JULI 2016

soal menggunakan rumus koefisien korelasi biserial $(\gamma$ pbi) kemudian menentukan realibilitas koefisien instrument dengan menggunakan rumus K-R. 20.

\section{Teknik Pengumpulan Data}

Pengumpulan data dalam penelitian ini dilakukan dengan pemberian tes awal (pretest) dan tes akhir (posttest) pada kelas eksperimen dan kelas kontrol. Jenis data berupa hasil belajar. Tes tersebut dilakukan secara serentak setelah eksperimen dilakukan baik pada kelompok eksperimen, maupun kelompok kontrol. Selain tes hasil belajar, juga diberikan angket respon siswa dan observasi kegiatan siswa terhadap kelompok eksperimen dan kelompok kontrol.

\section{Teknik Analisis Data}

Data yang diperoleh dari hasil penelitian ini dianalisis dengan teknik analisis statistika deskriptif untuk menggambarkan karakteristik hasil belajar siswa yang meliputi : nilai tertinggi, nilai terendah, nilai rata-rata, standar deviasi dan tabel distribusi frekuensi, dan teknik analisis statistika inferensial yang digunakan untuk menguji hipotesis penelitian dengan menggunakan uji-Anakova. Namun sebelum dilakukan pengujian hipotesis, terlebih dahulu dilakukan uji normalitas dan homogenitas.

\section{Analisis Data Angket Respon Siswa}

Data hasil angket dianalisis dengan cara mencari persentase tiap pilihan. Kriteria untuk menyatakan bahwa model pembelajaran tersebut efektif berdasarkan respons siswa, yaitu apabila banyaknya siswa yang memberi respons positif lebih besar atau sama dengan $80 \%$ dari jumlah subjek uji coba.

\section{Analisis Hasil Observasi Aktivitas Siswa}

Data hasil pengamatan aktivitas siswa yang muncul dari setiap sintaks pembelajaran atau langkah-langkah pembelajaran kedua kelompok penelitian dideskripsikan dalam bentuk ratarata banyaknya persentase siswa yang melakukan aktivitas untuk setiap kategori aktivitas siswa dalam proses pembelajaran matematika.

\section{HASIL DAN PEMBAHASAN}

Deskripsi mengenai kemampuan awal siswa pada kelas kontrol yaitu kelas yang diajarkan dengan menggunakan model pembelajaran langsung

Hasil statistik yang berkaitan dengan skor kemampuan awal siswa pada kelas kontol diketahui bahwa dari 37 orang siswa yang menjadi sampel penelitian, 14 siswa berada pada kategori sangat rendah, 16 siswa berada pada katgeori rendah, dan 7 siswa pada kategori sedang. Skor rata-rata kemampuan awal siswa SMPN 18 Makassar adalah 50,95, maka disimpulkan bahwa kemampuan awal siswa dikategorikan rendah.

Deskripsi mengenai kemampuan awal siswa pada kelas eksperimen yaitu kelas yang diajarkan dengan menggunakan model pembelajaran make a match

Hasil statistik yang berkaitan dengan skor kemampuan awal siswa pada kelas eksperimen diketahui bahwa dari 34 orang siswa yang menjadi sampel penelitian, 11 siswa 
berada pada kategori sangat rendah, 17 siswa pada kategori rendah, dan 6 siswa berada pada kategori sedang. Skor rata-rata kemampuan awal siswa SMPN 27 Makassar adalah 52,79 yang menunjukkan bahwa kemampuan awal siswa berada pada kategori rendah.

Deskripsi mengenai hasil belajar matematika siswa setelah diajar melalui model pembelajaran langsung

Hasil statistik yang berkaitan dengan hasil belajar matematika siswa setelah diajar melalui model pembelajaran langsung diketahui bahwa dari 37 orang siswa yang diberikan tes akhir (posttest), 5 siswa berada pada kategori rendah, 21 siswa pada kategori sedang, 10 siswa berada pada kategori tinggi, dan 1 siswa pada kategori sangat tinggi. Skor rata-rata hasil belajar matematika siswa SMPN 18 Makassar adalah 68,78 yang menunjukkan bahwa hasil belajar matematika siswa tersebut berkategori sedang.

\section{Deskripsi mengenai hasil belajar matematika siswa setelah diajar melalui model pembelajaran make a match}

Hasil statistik yang berkaitan dengan skor hasil belajar matematika setelah diajar melalui pembelajaran make a match diketahui bahwa dari 34 orang siswa yang menjadi sampel penelitian dalam kelas eksperimen, 17 siswa berada pada kategori tinggi dan 17 siswa berada pada kategori sangat tinggi. Skor rata-rata hasil belajar matematika siswa SMPN 27 Makassar setelah diajar menggunakan model pembelajaran make a match adalah 82,21, maka dapat disimpulkan bahwa hasil belajar matematika siswa tersebut dikategorikan tinggi.

\subsection{Hasil Analisis Statistika Inferensial}

a. Uji Normalitas

Hasil Perhitungan yang diperoleh untuk nilai posttest diperoleh $p$-value $>\alpha$ (taraf signifikansi $\alpha=0,05$ ) yaitu $0.104>0,05$. Kriteria pengujiannya adalah data berdistribusi normal jika $p$-value $>\alpha$ sehingga dapat disimpulkan bahwa nilai posttest termasuk pada kategori normal.

b. Uji Homogenitas

Dengan Program Statistical Package for Social Science (SPSS) perhitungan homogenitas variansi populasi diperoleh nilai $p=0.232$ dimana nilai $p>\alpha$, maka dapat disimpulkan bahwa variansi populasi kedua kelompok adalah sama (homogen).

c. Uji Hipotesis

Hasil analisis menunjukkan bahwa signifikasi 0.000 , karena nilai $\quad$ sig $<\alpha=0.05$ maka $\mathrm{H}_{0}$ ditolak atau $\mathrm{H}_{1}$ diterima. Ini berarti bahwa setelah memperhitungkan/mengontrol kemampuan awal siswa, terdapat perbedaan antara hasil belajar matematika yang diajar melalui model pembelajaran langsung dengan hasil belajar matematika yang diajar melalui model pembelajaran make a match.

\subsection{Hasil Analisis Angket Respon Siswa}

Hasil analisis angket kelas control terlihat dengan jelas bahwa dari 37 orang siswa di SMPN 18 makassar ada 25 orang siswa atau 67,57\% tidak setuju dengan penggunaan model 
JURNAL SAINTIFIK VOL.2 NO.2, JULI 2016

pembelajaran langsung yang digunakan untuk menarik perhatian mereka dalam belajar, selain itu hanya ada 3 siswa atau $8,1 \%$ yang mengatakan bahwa model pembelajaran langsung yang digunakan oleh guru membuat mereka lebih aktif. Hal ini menunjukkah bahwa siswa memberikan respon negatif terhadap model pembelajaran langsung yang diberikan oleh guru.

Hasil analisis angket respon siswa pada kelas eksperimen menunjukkan bahwa siswa sangat senang dengan model pembelajaran make a match yang digunakan oleh guru, hal ini terlihat dari 34 orang siswa atau 100\% mengatakan bahwa model pembelajaran make a match membuat mereka lebih tertarik dalam belajar serta merasa aktif dalam proses pembelajaran. Sehingga dapat dikatakan bahwa respon siswa terhadap model pembelajaran make a match adalah positif.

\subsection{Hasil Analisis Observasi Aktivitas Siswa}

Berdasarkan hasil observasi aktivitas siswa pada kelas kontrol, maka dapat dibuat rangkuman seperti yang terdapat pada tabel berikut:

Tabel. Hasil Analisis Observasi Aktivitas Siswa

\begin{tabular}{|c|c|c|c|c|c|}
\hline \multirow[b]{2}{*}{ No } & \multirow[b]{2}{*}{ Aktivitas } & \multicolumn{2}{|c|}{ Kelas Kontrol } & \multicolumn{2}{|c|}{ Kelas Eksperiment } \\
\hline & & $\begin{array}{l}\text { Rata- } \\
\text { Rata }\end{array}$ & $\begin{array}{c}\text { Persentas } \\
\text { e }\end{array}$ & $\begin{array}{l}\text { Rata- } \\
\text { Rata }\end{array}$ & Persentase \\
\hline 1 & $\begin{array}{l}\text { Kehadiran dalam } \\
\text { pembelajaran }\end{array}$ & 34.5 & $93,24 \%$ & 32.29 & $94,97 \%$ \\
\hline 2 & $\begin{array}{l}\text { Memperhatikan dan mencatat } \\
\text { informasi yang disampaikan } \\
\text { guru/siswa }\end{array}$ & 26.29 & $71,05 \%$ & 31.07 & $91,38 \%$ \\
\hline 3 & $\begin{array}{l}\text { Mengajukan pertanyaan } \\
\text { kepada teman/ guru }\end{array}$ & 3 & $8,11 \%$ & 7.71 & $22,68 \%$ \\
\hline 4 & $\begin{array}{l}\text { Aktif pada saat guru } \\
\text { menyajikan materi pelajaran }\end{array}$ & 28.93 & $78,19 \%$ & 31.14 & $91,59 \%$ \\
\hline 5 & $\begin{array}{l}\text { Mengerjakan Soal yang } \\
\text { diberikan }\end{array}$ & 32 & $86,49 \%$ & 32.29 & $94,97 \%$ \\
\hline 6 & $\begin{array}{l}\text { Menyampaikan kesimpulan } \\
\text { materi yang dipelajari }\end{array}$ & 2.07 & $5,59 \%$ & 17.79 & $52,32 \%$ \\
\hline 7 & $\begin{array}{l}\text { Melakukan kegiatan yang } \\
\text { tidak berkaitan dengan } \\
\text { pembelajaran }\end{array}$ & 5.57 & $15,05 \%$ & 0.86 & $2.53 \%$ \\
\hline
\end{tabular}

\subsection{Pembahasan Hasil Penelitian}

Berdasarkan hasil penelitian, data menunjukkan bahwa skor rata-rata nilai hasil belajar matematika secara deskriptif, siswa yang diajar melalui model pembelajaran make a match memberikan hasil yang lebih tinggi dibandingkan siswa yang diajar melalui model pembelajaran langsung. Hasil analisis inferensial menunjukkan bahwa secara signifikan terdapat perbedaan hasil belajar matematika siswa yang diajar dengan menggunakan model pembelajaran make a match dengan siswa yang diajar menggunakan model pembelajaran 
langsung dimana kemampuan awal siswa sebagai kovariat. Hal ini ditunjukkan oleh nilai $p=$ $0,000<\alpha=0.05$. Perbedaan ini juga dapat dilihat dari rata-rata hasil belajar matematika yang diperoleh oleh kedua kelompok.

\section{KESIMPULAN}

Berdasarkan hasil analisis data dan pembahasan di atas maka dapat disimpulkan bahwa: Hasil belajar matematika siswa yang diajar dengan model pembelajaran make a match lebih tinggi daripada hasil belajar matematika siswa yang diajar dengan model pembelajaran langsung.

\section{DAFTAR PUSTAKA}

Badan Penelitian dan Pengembangan. (2012). Hasil TIMSS 2007, diambil dari: http://litbangkemdiknas.net/detai.php?id=214, pada 31 Maret 2014.

Joyce, B., Weil, M., \& Calhoun, E. (2011). Models of Teaching (Model-Model Pengajaran) ( $8^{\text {th }}$ ed.). Yogyakarta: Pustaka Pelajar.

Slameto. (2010). Belajar dan Faktor-Faktor yang Mempengaruhinya. Jakarta: PT Rineka Cipta.

Slavin, R. (1995). Cooperative Learning: Theory, Research, and Practice. $\quad$ Bandung: Nusa Media.

Suprijono, A. 2009. Cooperative learning teori dan aplikasi PAIKEM. Yogyakarta: Pustaka Pelajar.

Trianto. 2007. Model-Model Pembelajaran Inovatif Berorientasi Konstruktivistik. Jakarta: Prestasi pustaka.

Usman, M. (2002). Menjadi Guru Profesional. Bandung: PT.Remaja Rosdakarya. 